\title{
Caps on noneconomic damages' effect on the number of paid malpractice claims in various American states
}

\author{
David B. Muhlestein ${ }^{* 1,2}$, Abigail Shoben ${ }^{1}$, Thomas Wickizer ${ }^{1}$ \\ ${ }^{1}$ The Ohio State University College of Public Health, Columbus, Ohio, United States \\ ${ }^{2}$ Leavitt Partners, Salt Lake City, Utah, United States
}

Received: February 4, 2016

DOI: $10.5430 /$ ijh.v2n2p45

\author{
Accepted: April 17, 2016 \\ Online Published: May 27, 2016 \\ URL: http://dx.doi.org/10.5430/ijh.v2n2p45
}

\begin{abstract}
Background: Tort reform with caps on noneconomic damages, such as pain and suffering, has been proposed as a way of decreasing the national cost of healthcare in the United States. In this paper we measure the impact of noneconomic damage caps at the state level.

Methods: Changes in the rate of paid claims are estimated using an interrupted time series design which identifies changes in trends following the implementation of an intervention. Data from the National Practitioner's Data Bank are used to create yearly trends in state malpractice claims using a linear spline model with a knot at the year that noneconomic caps were implemented to estimate the effect of the noneconomic caps. The effect of statutes of limitations are also modeled with a spline model. Finally, a difference-in-difference design matches states that instituted or significantly changed noneconomic caps to states that did not. Findings: Of the fifteen states that implemented caps on noneconomic damages or significantly changed their caps since 2000 , two had statistically significant differences in the absolute number of paid claims and six had significant changes to their trend of paid claims.

Conclusions: Tort reforms that address caps on noneconomic damages, though facially similar, have significantly different results when implemented in individual states. Qualitative studies of the individual state policies need to evaluate how the state policies differ and why they led to different results to direct other states and the federal government as they consider similar policies.
\end{abstract}

Key Words: Malpractice, Tort reform, Noneconomic damages, American healthcare

\section{BACKGROUND}

The cost of healthcare has become a significant financial burden for the United States. Tort reform has been proposed as a means of lowering its growth. ${ }^{[1-5]}$ Proponents believe that this will lower costs in two ways: (1) by lowering malpractice premiums ${ }^{[6]}$ and (2) by decreasing defensive medicine. ${ }^{[7]}$ The former concept infers that the high costs of insuring against malpractice lead to physicians transferring those costs to patients and insurers. The assumption is that if physicians have lower premiums they will also be willing to lower their prices. The latter way is based on the belief that physicians, due to a desire to not be sued, will order excessive tests, procedures and care on the chance that the patient has a serious illness. This is particularly believed to result in higher service utilization among high-risk specialties (such as emergency department physicians and obstetricians) ${ }^{[8]}$ and higher rates of diagnostic imaging. ${ }^{[9]}$ Various versions of tort reform have been implemented in different states, but

\footnotetext{
* Correspondence: David B. Muhlestein, PhD JD; Email: david.muhlestein@leavittpartners.com; Address: 299 S Main St, Suite 2300, Salt Lake City, UT 84087, United States.
} 
no national model is in place - this allows researchers to evaluate the effects of various forms of tort reform; in this paper we evaluate the impact of one type of tort reform: caps on noneconomic damages.

One approach to tort reform is to place limits, or caps, on noneconomic damages. Within a tort claim there are two claims that a plaintiff may make: claims for compensatory or actual damages and claims for punitive or exemplary damages; the latter type of damages intend to punish the tortfeasor (the party that committed the tort) while the former intend to make the victim whole. ${ }^{[10]}$ Within the damages category there are two general types of damages: economic losses and noneconomic losses. ${ }^{[11]}$ Economic losses include claims where a dollar value is assignable such as the reasonable cost of necessary medical care ${ }^{[11]}$ and the loss of income due to the injury. ${ }^{[1]}$ Noneconomic illnesses are subjective and include claims for pain and mental suffering. ${ }^{[11]}$ A common form of state tort reform addresses these noneconomic damages, usually relating to pain and suffering, and places an upper limit on the damages that can be awarded to the patient due to a malpractice claim. ${ }^{[12]}$

The goal of a cap on noneconomic damages is to limit the potential liability for a medical malpractice claim. The argument is that if there is a limit to the total amount of noneconomic damages, then there will be a smaller chance of extremely high awards for victims as the award will primarily be limited to objective, economic damages. The end result, according to this argument, is that overall awards will decrease which will lead to lower premiums and, thus, lower prices charged by physicians. Subsequently, if physicians have less fear of being sued, they will also change their practice habits and decrease the practice of defensive medicine. Caps, though, do not guarantee lower costs. There are often exceptions to the noneconomic caps, such as for the loss of a limb or permanent loss of function, ${ }^{[13]}$ and the actual damages may exceed any noneconomic damages.

A criticism of this approach is that caps will lead to the unintended consequence of reducing access to the system for those with legitimate claims. Critics argue such caps make lawyers less willing to take meritorious cases which will leave deserving patients - those that suffered a legitimate tort - without access to begin the legal process. ${ }^{[14]}$ In the United States, a civil tort claim may be brought by an individual without representation, but, in practice, without an attorney individuals will not successfully argue a claim. ${ }^{[15,16]}$ Additionally, there is the issue of administrative cost as legal cases are generally protracted, expensive affairs. ${ }^{[17]}$ For an average person to gain access to the system, he or she typically must rely on attorneys who believe that the individual has a valid case and agree to represent the client and also furnish much of the cost of the trial. ${ }^{[18]}$ The attorney will work on a contingency fee wherein, if the client's claim is successful, the attorney will be paid a percentage of the final verdict. The attorney, then, must be willing to bear some amount of risk to accept a case as, if they do not win, they attorney will not be paid anything but may lose the expenses of litigation. If there are caps put on noneconomic damages, then some individuals, particularly those that have low economic losses (such as the elderly who are unemployed and thus do not suffer any lost earnings), will have smaller potential claims. By decreasing the maximum award for the litigation, attorneys have a smaller potential return on their investment of time and resources. Thus, the argument goes, with a smaller potential return with some cases, they will be less likely to take on those clients, leaving individuals without potentially meritorious claims without access to the legal system. The question that this study addresses is whether individuals without potentially meritorious claims are left without access to the legal system.

If individuals without potentially meritorious claims are indeed left without access into the system, then there is an expectation that the number of malpractice claims (i.e., cases wherein a payment for malpractice is made, either as the result of a jury verdict or as the result of a pre-trial settlement) will decrease due to reforms that impose caps on noneconomic damages. This study does not seek to address whether the size of the average paid claim is affected by states putting caps on noneconomic damages nor does it address the effect on malpractice premiums and medical costs; it is limited to evaluating whether tort reforms limit access to the legal system for meritorious claims. The assumption is that claims that are paid are meritorious. While there are cases where individual claims may be paid as a result of settling nuisance lawsuits, the vast majority of paid settlements are a result of a medical error having, in fact, occurred. ${ }^{[19]}$

Previous studies evaluating tort reform have focused on the number of filed lawsuits, the size of awards and the cost of insurance. ${ }^{[20]}$ Some studies, though, have investigated whether tort reform affects the number of paid settlements. One study, looking at data through 2005 and using a regression model evaluating six different types of reforms found that tort reform was associated with a decrease in the number of paid claims. ${ }^{[21]}$ A second study using instrumental variables to control for policy endogeneity and evaluating tort reforms implemented between 1991 and 2001 found no effect of caps on noneconomic damages on the number of paid claims. ${ }^{[22]}$ There is significant variation in tort reform bills among states, meaning that a state-specific analysis will have some advantages to a national analysis including the 
ability to match to specific, similar states to use as controls and to adjust for state-specific differences in the timing of tort-reform bills.

A challenge with measuring whether there is an effect of such tort reforms on the number of paid malpractice claims relates to the timing of the implementation of the tort reforms, which varies by state. While tort reforms generally have a specific day in which they were passed, signed and became effective, their effect on a specific case varies. Statutes of limitations for claims may last for several years in states which affect whether the tort reforms apply to a specific case. For example, an injury that occurred on 12/31/2005 will not be covered by a law that imposes a cap on noneconomic damages that is effective on $1 / 1 / 2006$. If there is a three-year statute of limitations to file a claim, then that claim may be filed until 12/31/2008 without the caps affecting it. Some states, though, will make new laws effective retrospectively, eliminating this possibility. Additionally, statutes of limitations may vary based on numerous factors including the age of the claimant (children usually have longer to file, sometimes after they turn 18) and when the adverse event was known. For example, some states do not start tolling the statute of limitations until a patient learns of alleged malpractice (such as learning of a sponge left in their body following a surgery several years after the surgery) but often do have maximum time periods following the initial action (such as the surgery) which are binding. For example, in Florida there is a two-year statute of limitations to bring a claim, but the statute does not begin to toll until the patient learns of the harm, but all claims must be brought within four years. That means that if a patient learns of the harm three years following an operation, they will only have one year to file the claim before the four-year maximum is met.

Additionally, there are often constitutional challenges to tort reform bills which lead to uncertainty in whether caps will actually stand, leading some attorneys to continue to take cases and then to challenge the caps on noneconomic damages on state constitution grounds or to avoid cases while waiting for decisions about the constitutionality of the law. ${ }^{[23]}$ A third issue relates to the timing of when attorney behavior may change. For example, as soon as a bill is proposed some attorneys may be tempted to shift their practice away from medical malpractice cases in an effort to avoid the issue all together; or, if attorneys decide to leave the state, it may take several years to arrange to move elsewhere due to licensure and employment. Such issues of timing must be accounted for when estimating the effects of state tort reform. This paper adds to the literature by specifically addressing the state-specific timing issues and by conducting multiple state-specific comparisons.

Published by Sciedu Press

\section{Significance}

Caps on noneconomic damages have been implemented by multiple states as one approach to mitigating healthcare cost growths. Of the 50 states and the District of Columbia, 27 have had caps on noneconomic damages at some point, and 24 had them in place as of $2010^{[24]}$ and they have been considered by others. Some states have implemented these caps multiple times after the original version of the law was declared unconstitutional by the individual state's Supreme Court. There have been four periods when these caps have been enacted: 1976 (2 states), 1986-1988 (13 states), 19951997 (6 states) and 2002-2006 (15 states), and more recently, states are considering new proposals. ${ }^{[25]}$

National tort reform with caps on noneconomic damages has been proposed as a way of decreasing costs in health care. ${ }^{[26]}$ In March of 2012, the United States House of Representatives passed a bill imposing national caps on noneconomic damages. ${ }^{[27]}$ While the bill was never passed by the Senate, the passage of the bill by the House indicates it is a seriously considered policy. As some states have already enacted these laws, they serve as test cases to estimate the effect such a policy would have on the national level. By evaluating statelevel effects of tort reform on the number of paid malpractice claims, if any, on the states, an estimate of the effect of a national policy may have on the number of malpractice claims may be created. This study seeks to gain insight into the potential effect of such a national policy and to guide policy makers as they evaluate the wisdom of such a policy.

The focus of this research will be limited to the impact of caps on noneconomic damages. This is because the proposed federal legislation's tort reform's primary focus is on caps and changes to joint and several liability. ${ }^{[27]}$ Joint and several liability reform is of less interest because only 11 states have not already adopted this reform and only five states did so during the past fifteen years (one of which, Pennsylvania, had its reforms ruled unconstitutional). In this paper we evaluate states that implemented a cap on noneconomic damages where no cap existed before and states that significantly changed their economic cap (either by increasing or decreasing the cap).

\section{Methods}

The statistical analyses relied on two different approaches: interrupted time series and a difference-in-difference analysis. The former was used to estimate any changes in trends of the number of paid claims while the latter allows direct comparisons to similar states without tort reform. For all analyses, the unit of analysis was the rate of paid claims, by state, per 1,000 physicians within that state. The time period for these reforms is 2002-2006. 
An interrupted time series design is used to estimate changes in trends following the implementation of some intervention. ${ }^{[28]}$ The general approach is to regress trends before and after the intervention and evaluate whether the slope or intercept of the regressed lines (centered at the time of the intervention) change. Such a design has been used previously to estimate the effects of policy changes such as the effect of quality reporting on mortality rates. ${ }^{[29]}$ The approach requires the assumption of independence among yearly estimates. In this case, that requires a belief that the individual paid malpractice claims are independent of previous years' claims. Since each instance of malpractice is unique (i.e., not driven by past instances), this assumption is met.

The challenge with using an interrupted time series to estimate such a change is the difficulty in establishing a clear time frame in which a cap on a noneconomic damage affects behavior. Due to issues with effective dates, statutes of limitations, constitutional challenges, and attorney behavior, there is not a discrete time when the reform goes into effect. To address this challenge, we evaluated states that implemented tort reform and model the time the law was passed and at the end of the statute of limitations for claims that occurred before the law was passed. The expected result, if there is any effect from the tort reform, is a gradual decrease in the number of paid claims from the time of the passage of the bill to the end of the statute of limitations and then a similar trend in the number of paid claims as there was prior to the change in the law. Alternatively, there could be a change in the intercept (a change in the absolute number of paid claims) either at the time of the bill's passage or at the end of the statute of limitations.

A second tool to evaluate these claims relied on a differencein-difference (DiD) design. ${ }^{[28]}$ In this approach, states which made a change to their caps on noneconomic damages are compared to states that did not have changes. To accomplish this, we first matched states to a suitable control state by matching the intervention state (the state that changed its caps on noneconomic damages) to: (1) the state that, up to the year before the law was passed, had the most similar trend in the rate of paid claims, and (2) the state that had the most similar total number of paid claims. We then evaluated whether there is a difference between the subsequent rates of paid claims between the state that changed its cap on noneconomic damages and the state that did not.

In other analyses of tort reform, a single reform, including caps on noneconomic damages, were evaluated in a fixed effects model. ${ }^{[30]}$ In these regression analyses, state effects were combined and an average effect was estimated for that particular reform. ${ }^{[21]}$ In our analysis, we do not identify an average effect from noneconomic caps, but instead focus on estimating a state-level impact of this reform. Due to state-specific factors and variations in the implementation of the tort reform, a statute that is facially similar may have different effects once put in effect, and we sought to identify these differences.

\subsection{Data}

The primary data set that we used to perform this study is the National Practitioner Data Bank (NPDB). Established by Congressional order, the NPDB contains information on malpractice payments made by, and adverse actions taken against, healthcare providers including physicians, dentists and other healthcare practitioners. ${ }^{[31]}$ By law, all paid malpractice claims must be reported to the NPDB within a month of the claim or settlement being paid. ${ }^{[31]}$ The NPDB, then, contains a census of malpractice claims paid since 1990 . We used information on the number of settlements that occurred by year in individual states in this study. Since the first year's reporting began midyear, we used full year data beginning in 1991. Figure 1 shows the number of claims and average claims broken down by states that had a cap on noneconomic damages in place at some point and those that never had a cap.

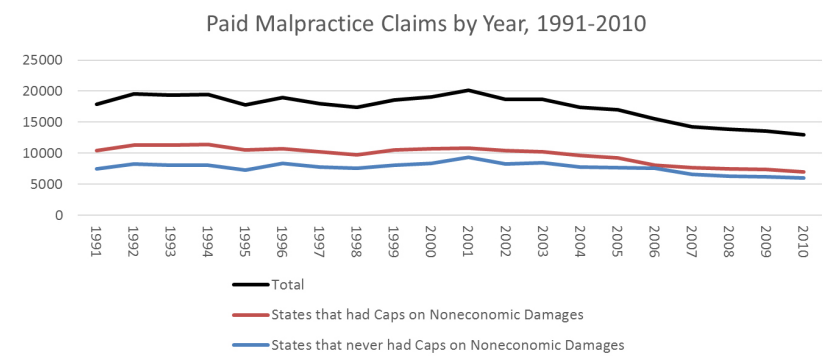

Figure 1. Malpractice trends, 1991-2010

To obtain the rate of claims per 1,000 physicians we estimated the number of physicians in each state. The Area Resource File (ARF) is a database compiled by the Health Resources and Services Administration that contains information on healthcare resources, including physicians, at the county level which we use to calculate state-level values. ${ }^{[32]}$ While some previous research has used the number of claims divided by the population of the state, ${ }^{[22]}$ we used the number of claims per 1,000 physicians following previous work. ${ }^{[21]}$ This approach better reflects the volume of care delivered in a state as patients may travel across state lines to receive care but physicians rarely travel across state lines to provide care due to state-level medical licensing. The total number of physicians was calculated by combining the number of non-federal, practicing MDs (allopathic physicians) and 
DOs (osteopathic physicians). The ARF does not contain estimates for all years of each type of physician, so when a year of data is missing we approximate the number of physicians by averaging the reported years' values (i.e., if 2009 MDs is missing, we average 2008 MDs and 2010 MDs).

For information on the different reforms that have been implemented, we used the Database of State Tort Law Reforms, $4^{\text {th }}$ Edition (DSTLR4). ${ }^{[24]}$ This database is a compendium of state tort reform laws including information on when they were passed, modified and whether and when they were found to be unconstitutional. An accompanying analytic file contains information on the types of reforms in effect in states by year and the level of the caps. The analytic files assign a year as having a tort reform in place if the reform was in effect for a majority of the year; for example, a law effective June 30, 2004 is coded as "in effect" for 2004, but a law with an effective date of July 1, 2004 is not coded as being in effect until 2005. The DSTL4 is current through 2010, which represents the final year of the study.

We focused on states that implemented or significantly changed caps on noneconomic damages after 2000. Table 1 includes general information on these states. Note that Utah and Wisconsin significantly raised their caps during this period and that Illinois' caps were only in place for two years.

Table 1. States that modified caps on noneconomic damages 2000-2010

\begin{tabular}{|c|c|c|c|c|c|}
\hline State & $\begin{array}{l}\text { Years } \\
\text { Enacted }\end{array}$ & $\begin{array}{l}\text { Cap } \\
(\$ 1,000 s)\end{array}$ & $\begin{array}{l}\text { Previous Cap } \\
(\$ 1,000 s)\end{array}$ & $\begin{array}{l}\text { Tort Statute of } \\
\text { Limitations } \\
\text { (Years) }\end{array}$ & Statute \\
\hline Alaska & 2006-2010 & 250 & 400 & 2 & Alaska Stat. § 09.55.549 \\
\hline Florida & 2003-2010 & 500 & No cap & 2 & Fla. Stat. § 766.118 \\
\hline Georgia & 2005-2010 & 350 & No cap & 2 & Ga. Code $§ ~ 51-13-1$ \\
\hline Idaho & 2004-2010 & $250-290$ & 650 & 2 & Id. Code § 6-1603 \\
\hline Illinois & 2006-2007 & 500 & No cap & 2 & 735 Ill. Compiled Stat. 5/2-1706.5 \\
\hline Mississippi & 2003-2010 & 500 & No cap & 2 & Miss. Code § 11-1-60 \\
\hline Missouri & 2006-2010 & 350 & 580 & 2 & Mo. Stat. § 538.210 \\
\hline Nevada & 2003-2010 & 350 & No cap & 1 & Nv. Stat. 41A.035 \\
\hline Ohio & 2003-2010 & 500 & No cap & 1 & Ohio Rev. Code § 2315.18 \\
\hline Oklahoma & 2004-2010 & 300 & No cap & 2 & 23 Okla. Stat. § 61.2 \\
\hline South Carolina & 2006-2010 & 350 & No cap & 3 & S.C. Code 15-32-220 \\
\hline Texas & 2004-2010 & 250 & No cap & 2 & Tex. Civ. Prac. \& Rem. 74.301 \\
\hline Utah $^{*}$ & 2002-2010 & $400-440$ & 250 & 2 & Ut. Code 1953 § 78B-3-410 \\
\hline West Virginia & 2003-2010 & 250 & 1,000 & 2 & W. Va. Code § 55-7B-8 \\
\hline Wisconsin ${ }^{*}$ & 2006-2010 & 750 & $350-450$ & 3 & Wisc. Stat. 893.55(4) \\
\hline
\end{tabular}

Note. Data for reform laws ended in 2010, states did not necessarily end their caps in 2010.

\subsection{Statistical models}

The general statistical model for this analysis was based on changes in temporal trends in the rate of paid malpractice claims using a linear spline model with a knot at the year that noneconomic caps were enacted. Data run from 19912010 and represent 20 points in time. Each state is analyzed separately using the following model:

$$
Y_{\text {year }}=\beta_{0}+\beta_{1}(\text { year })+\beta_{2}(\text { year }- \text { year_enacted })_{(\text {year-year_enacted }>0)}+\beta_{3}(\text { caps_enacted })
$$

$Y$ is the estimated number of malpractice payments per 1,000 physicians at time year. Year_enacted is the year that the noneconomic caps were enacted (the knot). Caps_enacted is a dummy variable that equals 1 if the noneconomic caps were enacted in the state during time year (e.g., caps_enacted
$=1$ if year-year_enacted $>0$ ). $\beta_{0}$ represents the baseline rate of claims in 1991 (the first complete year of the data). $\beta_{1}$ is the slope of the trend of paid claims prior to the change in the noneconomic caps policy (either implementing a new cap or changing an existing cap). $\beta_{2}$ is the change in slope 
of the trend line following implementation of the noneconomic caps (following the knot), so $\beta_{1}+\beta_{2}$ is the slope of trend line following implementation. $\beta_{3}$ is the change in the intercept at the time of implementation (the knot). If $\beta_{2}$ is significant, then there is evidence that following the implementation of noneconomic caps the trend in the rate of paid claims changed. If $\beta_{3}$ is significant, there is evidence that the absolute rate of paid claims changed at the implementation of noneconomic caps. Either a change in slope or intercept is indicative of a positive effect from the change in baseline. ${ }^{[28]}$ To evaluate the effect of the statute of limitations, the model is expanded to:

$$
\begin{aligned}
& Y_{\text {year }}=\beta_{0}+\beta_{1}(\text { year })+\beta_{2}(\text { year }- \text { year_enacted })_{\left(y e a r-y e a r \_e n a c t e d>0\right)}+\beta_{3}(\text { caps_enacted }) \\
& +\beta_{4}\left(y e a r-y e a r \_s t a t u t e \_l i m i t a t i o n s \_e n d\right)_{\left(y e a r-y e a r \_s t a t u t e \_l i m i t a t i o n s \_e n d>0\right)}+\beta_{5}(\text { statute_limitations_ended })
\end{aligned}
$$

The effect of this model is to add a second knot at the time that the statute of limitations ended. Year_statute_limitations_end represents the year the statutes of limitations end and statute_limitations_ended is a dummy variable that is 1 for each year once the statute of limitations have been reached. $\beta_{4}$ is the change in the slope following the end of the statute of limitations and $\beta_{5}$ is the change in the intercept at that point. $\beta_{1}+\beta_{2}+\beta_{4}$ equals the slope following the end of the statute of limitations. If $\beta_{4}$ is significant, then there is evidence that following the end of the statute of limitations there was a change in the trend of the rate of paid claims. If $\beta_{5}$ is significant, there is evidence that the absolute rate of paid claims changed after the end of the statute of limitations.

To evaluate the effects of noneconomic caps using a DiD approach, we first matched states that passed tort reform to control states that did not enact tort reform during this period (they may have implemented noneconomic caps prior to 1991, but did not do so during the period of the study). To match we regressed all states up to the year immediately prior to the year that the state in question implemented noneconomic caps (such as regressing all states up to 2002 to compare to Florida, whose noneconomic caps went into effect in 2003). We then matched the state to the closest control states based on the slope (the temporal trend of the rate of paid claims) and the absolute rate of paid claims, meaning each state has two controls. Once each state was matched, we regressed the state that implemented the noneconomic caps (the intervention state) and the states that did not (the control states) and evaluated the control states as if they implemented noneconomic caps at the same time as the intervention state. We then compared the change in slope $\left(\beta_{2}\right)$ between the intervention state and the trend control state and change in intercept $\left(\beta_{3}\right)$ between the intervention state and the absolute rate control state.

All analysis was done using Stata version 12.1 and used user-written commands bigtab and estout. ${ }^{[33-35]}$

\subsection{Limitations}

A difficulty with estimating the effects of policies is the timing of these policies arises from not knowing when a policy may have affected individual behavior. As described in the methods, we model the end of the statutes of limitations to see if they affect estimates of the effects of the policy change, but we are able to access individuals or person-specific information.

A second limitation relates to concurrent changes that could be causing a perceived change, independent of the policy change. Commonly, when one tort reform is passed, others are passed simultaneously. The challenge, then, is that the actual causal agent may not be the specific tort reform that we are investigating. To address this challenge, in addition to the interrupted time series, which is able to account for existing trends over time, we perform the matched pair difference-indifference analysis. This allows us to compare whether any similar change occurred in the control state. If there is no significant change from the control state, there is evidence that noneconomic caps did not lead to a change in the rate of paid claims. If there is a difference from the control states and there is a significant temporal or absolute change in the rate of paid claims, there is evidence of an association between noneconomic caps and an effect on paid claims, but there is the possibility that another aspect of the state's tort reform that was the causal factor. A positive correlation, though, is evidence that potentially deserving claimants did lose access to the legal system because the rate of paid claims decreased differently than past trends would predict.

A third limitation arises from the dataset. In an effort to make identifying a specific person reported on the NPDB difficult, data is not presented in the most granular form possible. In particular, all data is based on full years, thus only 20 data points for each state are available for analysis. This limits 
precision when estimating any effects of a policy, particularly relating to any delayed implementation effects such as those that may arise as a result of the various statutes of limitations.

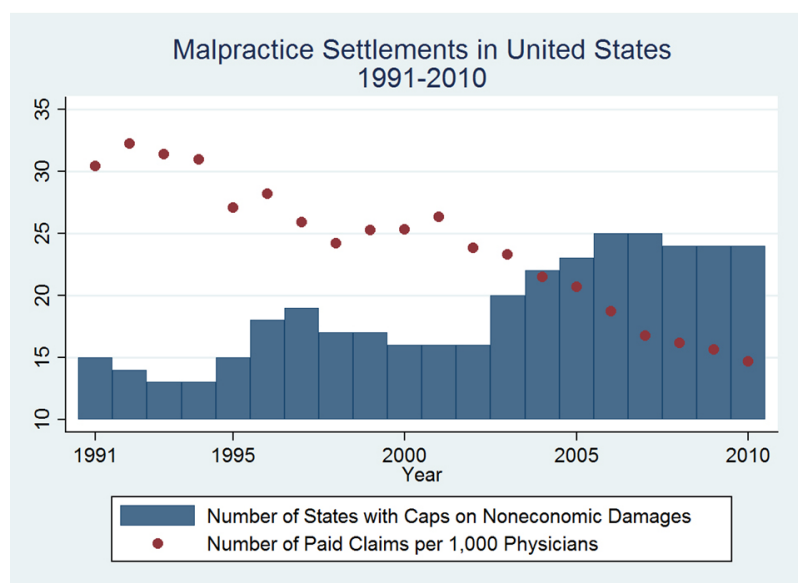

Figure 2. Paid malpractice claims per 1,000 physicians in the United States

\section{RESUlts}

Since the early 1990s, the rate of paid medical malpractice settlements has been dropping in the United States. Simultaneously, many states have implemented caps on noneconomic damages. Figure 2 charts the total number of paid claims per 1,000 physicians in the United States, with the bar chart representing the number of states that had enacted caps on noneconomic damages during this period. The rate of paid claims went from a high of 32.2 per 1,000 physicians in 1992 to a low of 14.7 per 1,000 physicians in 2010 with an annual decrease of .90 settlements per 1000 physicians $(p<.001)$. The number of states with caps on non-economic damages also increased at an annual rate of .64 states per year $(p<.001)$. Also, the total number of states with caps on noneconomic damages and the rate of paid claims is highly correlated $(-.931, p<.001)$.

Table 2. Effect of caps on noneconomic damages on paid claims

\begin{tabular}{llllll}
\hline State & Years in Effect & $\begin{array}{l}\text { Cap } \\
\mathbf{( \$ 1 , 0 0 0 s )}\end{array}$ & $\begin{array}{l}\text { Previous Cap } \\
\mathbf{( \$ 1 , 0 0 0 s )}\end{array}$ & $\begin{array}{l}\text { Change in Intercept } \\
\text { (Absolute Change) }\end{array}$ & $\begin{array}{l}\text { Change in Slope (Trend } \\
\text { Change) }\end{array}$ \\
\hline Alaska & $2006-2010$ & 250 & 400 & -0.623 & -0.598 \\
Florida & $2003-2010$ & 500 & No cap & -2.849 & $-2.425^{* * *}$ \\
Georgia & $2005-2010$ & 350 & No cap & -2.714 & $-1.385^{* * *}$ \\
Idaho & $2004-2010$ & $250-290$ & 650 & 2.986 & $-0.978^{*}$ \\
Illinois & $2006-2007$ & 500 & No cap & 0.874 & 0.479 \\
Mississippi & $2003-2010$ & 500 & No cap & $-8.557^{*}$ & -1.206 \\
Missouri & $2006-2010$ & 350 & 580 & 2.643 & -0.724 \\
Nevada & $2003-2010$ & 350 & No cap & 3.685 & $-2.215^{*}$ \\
Ohio & $2003-2010$ & 500 & No cap & -4.402 & -1.046 \\
Oklahoma & $2004-2010$ & 300 & No cap & 6.382 & -1.129 \\
South Carolina & $2006-2010$ & 350 & No cap & -1.466 & $-3.424^{* * *}$ \\
Texas & $2004-2010$ & 250 & No cap & 0.182 & $-1.681^{* * *}$ \\
Utah & $2002-2010$ & $400-440$ & 250 & 6.822 & 1.139 \\
West Virginia & $2003-2010$ & 250 & 1,000 & $-18.808^{* * *}$ & 0.321 \\
Wisconsin & $2006-2010$ & 750 & $350-450$ & 2.208 & 0.773 \\
\hline
\end{tabular}

The correlation between caps on noneconomic damages and paid claims suggests that the caps may lead to a decrease in the rate of paid claims, but it is important to evaluate this trend in relation to the state-specific findings before drawing any firm conclusions. When evaluating individual states, though, it is important to consider the timing of the caps in relation to the decrease in the rate of paid claims. Table 2 contains the estimated effect of the caps on noneconomic damages on the number of paid claims, calculated by state.
Figure 3 contains the graphical representation of this effect for each of these states. Only two states saw a significant change in the total number of paid claims (the intercept) while six states saw a significant change in the slope (the trend change). Wisconsin and Utah, which greatly raised their caps, did not see a significant increase in the rate of paid claims.

Table 3 shows the results when the statute of limitations was 
added as a second knot. The percent change in R2 shows in- the second knot, but two states (Alaska and West Virginia) dicates improvement in fit of the model with this added data saw fits that improved by over $5 \%$. element. Most states saw very little improved fit by adding

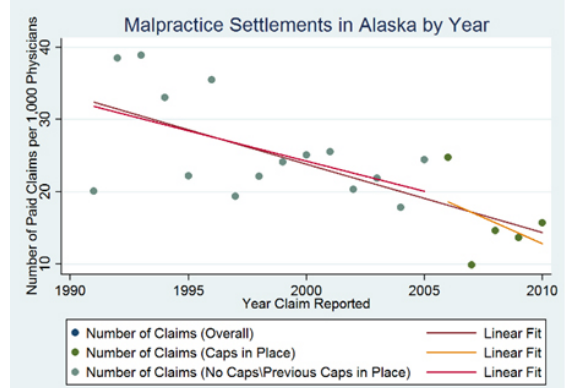

- Number of Claims (No Caps Previous Caps in Place) - Linear Fit
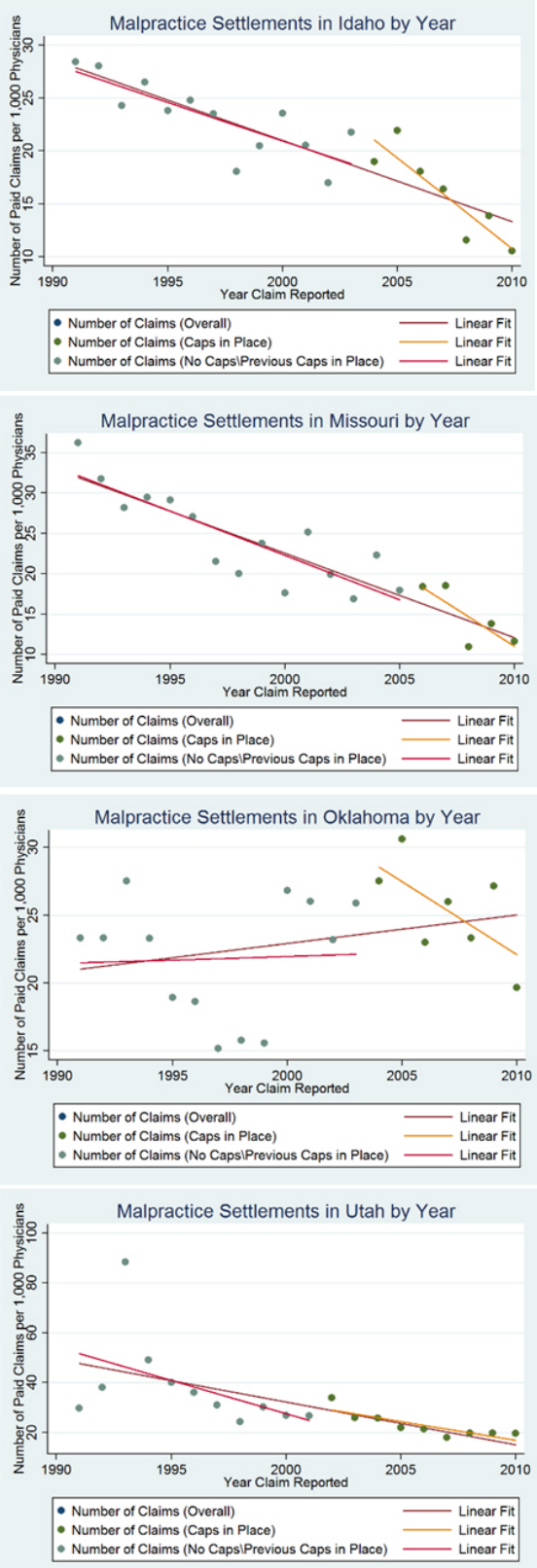
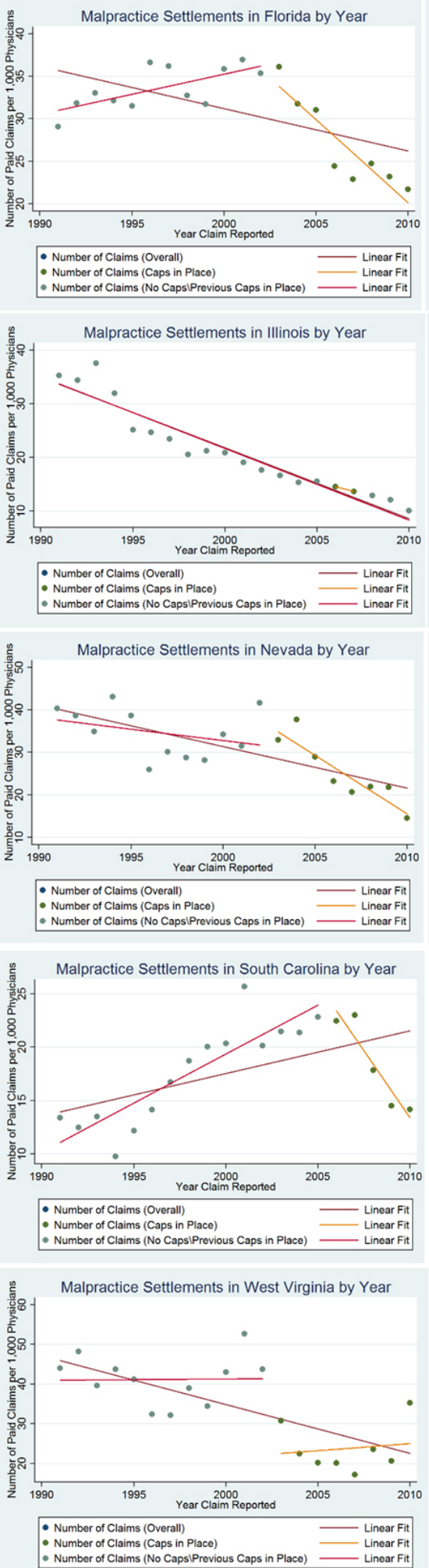
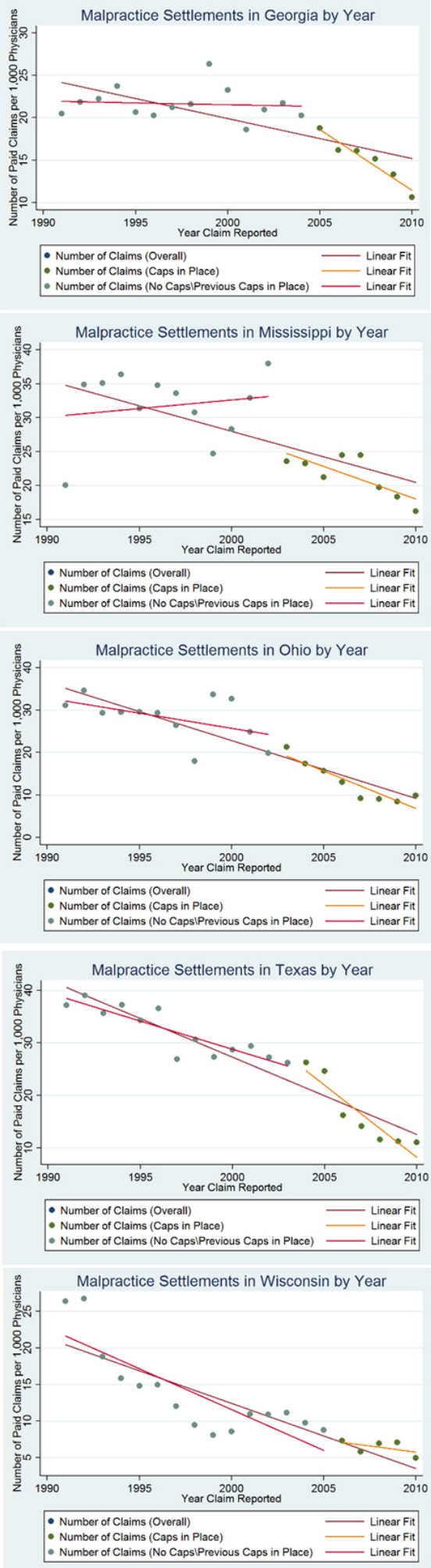

Figure 3. Effect of caps on noneconomic damages on paid claims, by state 
Table 4 shows the differences between states that changed caps on noneconomic damages compared to control states that did not. One state had a significantly different intercept compared to its control, and three states had significantly different slopes compared to their matched controls. Only two states, Nevada and Texas, had a significant change from both the control state and from their baseline trend.

Table 3. Effect of caps on noneconomic damages on paid claims with statute of limitations

\begin{tabular}{|c|c|c|c|c|c|c|c|c|}
\hline State & $\begin{array}{l}\text { Years in } \\
\text { Effect }\end{array}$ & $\begin{array}{l}\text { Cap } \\
(\$ 1,000 s)\end{array}$ & $\begin{array}{l}\text { Previous } \\
\text { Cap } \\
\text { (\$1,000s) }\end{array}$ & $\begin{array}{l}\text { Tort } \\
\text { Statute of } \\
\text { Limitations } \\
\text { (Years) }\end{array}$ & $\begin{array}{l}\text { Change in } \\
\text { Slope at } \\
\text { Implement } \\
\text { ation }\end{array}$ & $\begin{array}{l}\text { Change in } \\
\text { Slope at End of } \\
\text { Statute of } \\
\text { Limitations }\end{array}$ & $\begin{array}{l}\text { Statute of } \\
\text { Limitations } \\
\text { Model R2 - } \\
\text { Base Model } \\
\text { R2; Higher = } \\
\text { Better Fit }\end{array}$ & $\begin{array}{l}\text { Improvement } \\
\text { in R2 Over } \\
\text { Base Model } \\
(\%)\end{array}$ \\
\hline Alaska & 2006-2010 & 250 & 400 & 2 & -4.219 & 7.242 & 0.03 & $6.0 \%$ \\
\hline Florida & $2003-2010$ & 500 & No cap & 2 & -4.432 & 2.593 & 0.025 & $2.9 \%$ \\
\hline Georgia & $2005-2010$ & 350 & No cap & 2 & -1.007 & -0.602 & 0.001 & $0.2 \%$ \\
\hline Idaho & $2004-2010$ & $250-290$ & 650 & 2 & -0.239 & -1.034 & 0.003 & $0.4 \%$ \\
\hline Illinois & $2006-2007$ & 500 & No cap & 2 & 0.479 & Not in Effect & 0 & $0.0 \%$ \\
\hline Mississippi & $2003-2010$ & 500 & No cap & 2 & 0.119 & -1.713 & 0.006 & $0.9 \%$ \\
\hline Missouri & $2006-2010$ & 350 & 580 & 2 & -2.291 & 3.134 & 0.008 & $0.9 \%$ \\
\hline Nevada & $2003-2010$ & 350 & No cap & 1 & 0.836 & -3.328 & 0.005 & $0.8 \%$ \\
\hline Ohio & $2003-2010$ & 500 & No cap & 1 & -4.341 & 3.594 & 0.005 & $0.6 \%$ \\
\hline Oklahoma & $2004-2010$ & 300 & No cap & 2 & -1.663 & 0.748 & 0.002 & $0.9 \%$ \\
\hline South Carolina & 2006-2010 & 350 & No cap & 3 & -3.815 & 1.955 & 0.004 & $0.5 \%$ \\
\hline Texas & 2004-2010 & 250 & No cap & 2 & -4.581 & 4.06 & 0.015 & $1.5 \%$ \\
\hline Utah & $2002-2010$ & $400-440$ & 250 & 2 & -2.283 & 4.189 & 0.008 & $1.7 \%$ \\
\hline West Virginia & $2003-2010$ & 250 & 1,000 & 2 & -6.853 & 9.271 & 0.07 & $10.2 \%$ \\
\hline Wisconsin & $2006-2010$ & 750 & $350-450$ & 3 & 1.167 & -1.968 & 0.002 & $0.3 \%$ \\
\hline
\end{tabular}

\section{Discussion AND CONCLUSION}

This study has both important findings as well as implications. First, the effect of similar caps on noneconomic damages on the number of paid claims varies between states. A traditional approach to evaluating the effect of a tort reform is to put the tort reform into a regression along with all the other tort reforms and a state-specific variable and then estimate the average effect of the tort reform. Using 1991-2010 data, this combined approach estimates that caps on noneconomic damages, on average, decrease the rate of paid claims by about .31 per 1,000 physicians $(p=.028)$. This approach, though, ignores the extreme heterogeneity among states (the state-specific variable) which is of great interest to policy makers as similar reforms in different states have very different outcomes (see Table 2). The strong policy implication of this study is that there is more to tort reform than just the statutory language. As other states consider implementing caps on noneconomic damages or Congress continues to pursue national caps, attention needs to focus on the specifics of how the policy is implemented. Qualitative evaluation of the statutes, the rule regulations and the implementation process may be needed.

Second, even when there are significant effects on the num- ber of paid claims as a result of noneconomic caps, these effects are relatively minor. While some states had relatively significant changes in malpractice payment trends following implementation of noneconomic caps, when compared to a control state, these differences were quite small. This is because, independent of state-level tort reform, the trend has been towards fewer malpractice payments over time.

There are several potential reasons some states had significant changes in the rate of paid claims. The first is regression towards the mean which implies that extreme observances will tend to be less extreme (closer to the mean) in subsequent measurements. The two states with the most significant change in rate of paid claims, Florida and South Carolina, were respectively the second most and most extreme states in terms of trend of paid claims prior to implementing noneconomic caps. Regression towards the mean suggests that, simply because of their extreme position, their rates of paid claims would naturally move toward the average, independent of any change in policy.

A second possible reason for the significant drop in paid claims may be a historical effect. A likely possibility is the National Institutes of Health report "To Err is Human: Building a Safer Health System". ${ }^{[36]}$ Following that report's 
release, there began an intense national focus on improving patient safety and eliminating medical errors. ${ }^{[37]}$ The report was issued in November 1999 and beginning in 2001 there was a significant decrease in the national rate of paid claims $(p<.0001)$. Looking at states individually with 2001 as a knot, 18 states saw a significant drop in their number of paid claims. Thus, while tort reform may have been pursued as a means of limiting frivolous lawsuits, the effects of practitioners throughout the country limiting medical mistakes may have done more to reduce the number of paid malpractice claims.

Table 4. Differences between states that changed caps on noneconomic damages and those that did not

\begin{tabular}{|c|c|c|c|c|c|c|c|}
\hline State & $\begin{array}{l}\text { Years in } \\
\text { Effect }\end{array}$ & $\begin{array}{l}\text { Cap } \\
(\$ 1,000 s)\end{array}$ & $\begin{array}{l}\text { Previous } \\
\text { Cap } \\
(\$ 1,000 s)\end{array}$ & $\begin{array}{l}\text { Matched } \\
\text { State for } \\
\text { Intercept } \\
\text { (Absolute } \\
\text { Change) }\end{array}$ & $\begin{array}{l}p \text {-Value of } \\
\text { Change in } \\
\text { Intercept } \\
\text { from } \\
\text { Matched } \\
\text { State }\end{array}$ & $\begin{array}{l}\text { Matched } \\
\text { State for } \\
\text { Slope } \\
\text { (Trend) }\end{array}$ & $\begin{array}{l}p \text {-Value of Change in } \\
\text { Slope from Matched } \\
\text { State }\end{array}$ \\
\hline Alaska & 2006-2010 & 250 & 400 & Michigan & .8521 & Kansas & .8969 \\
\hline Florida & $2003-2010$ & 500 & No cap & Pennsylvania & .7037 & $\begin{array}{l}\text { District of } \\
\text { Columbia }\end{array}$ & .3484 \\
\hline Georgia & $2005-2010$ & 350 & No cap & Delaware & .7335 & $\begin{array}{l}\text { District of } \\
\text { Columbia }\end{array}$ & .0588 \\
\hline Idaho & 2004-2010 & $250-290$ & 650 & $\begin{array}{l}\text { New } \\
\text { Hampshire }\end{array}$ & .3525 & Louisiana & .0747 \\
\hline Illinois & 2006-2007 & 500 & No cap & Maine & .2405 & $\begin{array}{l}\text { New } \\
\text { Hampshire }\end{array}$ & .241 \\
\hline Mississippi & 2003-2010 & 500 & No cap & New Mexico & .4786 & $\begin{array}{l}\text { District of } \\
\text { Columbia }\end{array}$ & .3825 \\
\hline Missouri & 2006-2010 & 350 & 580 & Connecticut & .1912 & Indiana & $.003^{* *}$ \\
\hline Nevada & 2003-2010 & 350 & No cap & Kansas & .6313 & Massachusetts & $.0001^{* * * *}$ \\
\hline Ohio & $2003-2010$ & 500 & No cap & Washington & .4031 & Delaware & .8407 \\
\hline Oklahoma & 2004-2010 & 300 & No cap & Delaware & $.015^{*}$ & Hawaii & .1798 \\
\hline $\begin{array}{l}\text { South } \\
\text { Carolina }\end{array}$ & 2006-2010 & 350 & No cap & Kentucky & .4196 & Nebraska & .1764 \\
\hline Texas & 2004-2010 & 250 & No cap & Indiana & .1767 & Rhode Island & $.0001^{* * * *}$ \\
\hline Utah & $2002-2010$ & $400-440$ & 250 & Washington & .2789 & Michigan & .751 \\
\hline West Virginia & 2003-2010 & 250 & 1,000 & Wyoming & .4207 & Alabama & .5276 \\
\hline \multirow[t]{2}{*}{ Wisconsin } & 2006-2010 & 750 & $350-450$ & Minnesota & .8868 & Vermont & .4733 \\
\hline & & & & & & & $\begin{array}{r}{ }^{* * *} p<.001 \\
{ }^{* *} p<.01 \\
{ }^{*} p<.05\end{array}$ \\
\hline
\end{tabular}

From a policymaker's perspective, these results suggest that caps on noneconomic damages are unlikely to severely limit access of meritorious claims to the legal system. Simultaneously, the general trend towards fewer malpractice payments, independent of noneconomic caps, should raise questions as to whether tort reform really has the potential to decrease the cost of healthcare. During the study period, healthcare costs did not substantially decrease, despite the decrease in paid claims. Advocates of tort reform, rather than focusing on its potential cost-benefit, should instead evaluate whether it provides other, noneconomic benefits, such as increased numbers of providers who practice in the state or an elevation of the overall satisfaction of the healthcare workforce.

In conclusion, there is evidence that state caps on noneconomic damages have decreased the number of paid malpractice claims in a small number of states that enact such 
policies. The change, though, when compared to historical trends in similar comparison states, is modest. It appears that few people with meritorious claims will lose access to the legal system when states implement caps on noneconomic damages.

\section{CONFLicts OF INTEREST Disclosure}

The authors have no conflicts of interest to report.

\section{REFERENCES}

[1] Sloan S. House committee approves tort reform. Atlanta Business Chronicle [Internet]. 2005 Feb 4 [cited 2012 Jul 1]; Available from: http://www.bizjournals.com/atlanta/stories/ 2005/01/31/daily57.html?jst=b_ln_hl

[2] Krauthammer C. A Better Plan for Health-Care Reform. The Washington Post [Internet]. 2009 Aug 7 [cited 2012 Jul 1]; Available from: http: //www . washingtonpost . com/wp-dyn/content/a rticle/2009/08/06/AR2009080602933.html

[3] Eviatar D. Tort Reform Unlikely to Cut Health Care Costs. The Washington Independent [Internet]. 2009 Aug 19 [cited 2012 Jul 1]; Available from: http://washingtonindependent.com/55535/ tort-reform-unlikely-to-cut-health-care-costs

[4] Simmons J. Adding Tort Reform to Healthcare Reform Could Lower Costs. HealthLeaders Media [Internet]. 2009 Oct 12 [cited 2012 Jun 30]; Available from: http://www.healthleadersmedia.com/c ontent/FIN-240318/Adding-Tort-Reform-to-Healthcar e-Reform-Could-Lower-Costs.html

[5] Keene SW. News \& Record: Medical tort reform will save money. News \& Record [Internet]. 2011 Mar 9 [cited 2012 Jul 1]. Available from: http://www.news-record.com/content/2011/0 3/08/article/medical_tort_reform_will_save_money

[6] Morrisey MA, Kilgore ML, Nelson L (Jack). Medical Malpractice Reform and Employer-Sponsored Health Insurance Premiums. Health Serv Res. 2008 Dec; 43(6): 2124-42. PMid: 18522666. http://dx.doi.org/10.1111/j.1475-6773.2008.00869.x

[7] Kessler DP, McClellan M. Do Doctors Practice Defensive Medicine? [Internet]. National Bureau of Economic Research, Inc; 1996 [cited 2012 Jun 25]. Report No.: 5466. Available from: http://ideas . repec.org/p/nbr/nberwo/5466.html

[8] Studdert DM. Defensive Medicine Among High-Risk Specialist Physicians in a Volatile Malpractice Environment. JAMA J Am Med Assoc. 2005 Jun 1; 293(21): 2609-17. PMid: 15928282. http://dx.doi.org/10.1001/jama.293.21.2609

[9] Iglehart JK. The New Era of Medical Imaging - Progress and Pitfalls. N Engl J Med. 2006; 354(26): 2822-8. PMid: 16807422. http://dx.doi.org/10.1056/NEJMhpr061219

[10] Dietz L, Esping EK, Jacobs A, et al. American Jurisprudence, Second Edition. Damages [Internet]. 2012 [cited 2012 Jun 25]. (American Jurisprudence, Second Edition; vol. 22). Available from: http: //www. lexis. com/research/xlink?app $=00075 \& v i e w=f u l l$ \&searchtype $=$ get\&search $=22+\mathrm{Am}+\mathrm{Jur}+2 \mathrm{~d}+$ Damages $+\% \mathrm{~A} 7+25$

[11] Frumer LR, Friedman MI. Personal Injury: Actions, Defenses, Damages [Internet]. Mathew Bender; 2012 [cited 2012 Jun 25]. Available from: https://advance.lexis.com/GoToContentView?requ estid=ded34db9-2d41-45da-8708-23643dfa483b

[12] Thorpe KE. The Medical Malpractice "Crisis": Recent Trends And The Impact Of State Tort Reforms. Health Aff (Millwood) [Internet] 2004 Jan 21 [cited 2012 Jun 25]; Available from: http://conten t.healthaffairs.org/cgi/doi/10.1377/hlthaff .w4.20

[13] Ohio. \$2315.18 Compensatory damages in tort actions - factors excluded - findings or interrogatories. [Internet]. Ohio Revised Code
Apr 4, 2005. Available from: http://codes . ohio.gov/orc/231 5.18

[14] Hyman DA. Not Worth the Pain and Suffering - How caps on medical malpractice cases hurt the most vulnerable victims. Forbes [Internet]. 2008 Aug 21 [cited $2012 \mathrm{Jul}$ 1]; Available from: http: //www.forbes.com/forbes/2008/0915/034.html

[15] Landsman S. The Growing Challenge of Pro Se Litigation. Lewis Clark Law Rev. 2009; 13: 439.

[16] Haire SB, Hartley R, Lindquist SA. Attorney Expertise, Litigant Success, and Judicial Decisionmaking in the U.S. Courts of Appeals. Law Soc Rev. 1999; 33: 667. http://dx.doi.org/10.2307/3115107

[17] Harris GC, Foran DF. Ethics of Middle-Class Access to Legal Services and What We Can Learn from the Medical Profession's Shift to a Corporate Paradigm, The. Fordham Law Rev. 2001; 70: 775.

[18] Helland E. Contingency Fees, Settlement Delay, and Low-Quality Litigation: Empirical Evidence from Two Datasets. J Law Econ Organ. 2003; 19(2): 517-42. http://dx.doi.org/10.1093/jleo/ ewg019

[19] Studdert DM, Mello MM, Gawande AA, et al. Claims, Errors, and Compensation Payments in Medical Malpractice Litigation. N Engl J Med. 2006; 354(19): 2024-33. PMid: 16687715. http: //dx.doi.org/10.1056/NEJMsa054479

[20] Congressional Budget Office. The Effects of Tort Reform: Evidence from the States [Internet]. 2004 Jun [cited 2012 Jun 27]. Available from: http://www.cbo.gov/sites/default/files/ cbofiles/ftpdocs/55xx/doc5549/report.pdf

[21] Avraham R. An Empirical Study of the Impact of Tort Reforms on Medical Malpractice Settlement Payments. J Leg Stud. 2007 Jun 1; 36(S2): S183-229. http://dx.doi.org/10.1086/527332

[22] Durrance CP. Noneconomic Damage Caps and Medical Malpractice Claim Frequency: A Policy Endogeneity Approach. J Law Econ Organ. 2010; 26(3): 569-91. http://dx.doi.org/10.1093/jle ○/ewp022

[23] Avraham R. The Impact of Tort Reform on Medical Malpractice Payments [Internet]. 2006 [cited 2012 Jun 27] p. 74. (Northwestern Public Law Research Paper). Report No.: No 07-21. Available from: http://law.bepress.com/expresso/eps/1669/

[24] Avraham R. Database of State Tort Law Reforms (DSTLR 4th) [Internet]. The University of Texas School of Law; 2011 Sep [cited 2012 May 4]. (Law and Economics Research Paper). Report No.: No. 184. Available from: http://papers.ssrn.com.proxy.lib.oh io-state.edu/sol3/papers. cfm?abstract_id=902711

[25] National Conference of State Legislatures. Medical Malpractice Reform [Internet]. 2012 Aug [cited 2013 Mar 7]. (Health Cost Containment and Efficiencies). Report No.: 16. Available from: http://www.ncsl.org/issues-research/health/med ical-malpractice-reform-health-cost-brief .aspx

[26] Tumulty CB. Capping Non-Economic Damages: Is It really What the Doctor Ordered-Predicting the Effect of Federal Tort Reform by Examining the Impact of Tort Reform at the State Level. Suffolk UL Rev. 2005; 39: 817. 
[27] Gringey P. Protecting Access to Healthcare Act [Internet]. 5 Mar 22, 2012. Available from: http://www.gpo.gov/fdsys/pkg/BI LLS-112hr5eh/pdf/BILLS-112hr5eh.pdf

[28] Shadish WR, Cook TD, Campbell DT. Experimental and QuasiExperimental Designs for Generalized Causal Inference. Belmont, California: Wadsworth Cengage Learning; 2002. 666 p. PMid: 11928889.

[29] Ryan AM, Nallamothu BK, Dimick JB. Medicare's Public Reporting Initiative On Hospital Quality Had Modest Or No Impact On Mortality From Three Key Conditions. Health Aff (Millwood). 2012 Mar 1; 31(3): 585-92. PMid: 22392670. http://dx.doi.org/10.1377 /hlthaff.2011.0719

[30] Paik M, Black BS, Hyman DA, et al. Will Tort Reform Bend the Cost Curve? Evidence from Texas. J Empir Leg Stud. 2012; 9(2): 173-216. http://dx.doi.org/10.1111/j.1740-1461.2012.01251.x

[31] Secretary of Health and Human Services. National Practitioner Data Bank for Adverse Information on Physicians and Other Health Care Practitioners [Internet]. 45 Code of Federal Regulations, 99-660 Oct 17, 1989. Available from: http: //www. lexis.com/research/retrieve?_m=d404832 bf 22c3f7401db2520e2490f6d\&csvc $=1$ t\&cform=\&_fmtst $r=F$ ULL\&docnum=1\&_startdoc $=1 \& \mathrm{w} c h p=d G L z V z k-z S k A W \& \_m d 5=$ 1ef 14971 f62bdb0665b522d22a4c4574
[32] Health Resources and Services Administration. ARF: Area Resource File Overview [Internet]. 2012 [cited 2012 Jun 27]. Available from: http://arf.hrsa.gov/overview.htm

[33] StataCorp. Stata Statistical Software: Release 12. College Station, Texas: StataCorp LP; 2012.

[34] Bern PH. BIGTAB: Stata module to produce frequency tables for "too many values" [Internet]. Boston College Department of Economics; 2003 [cited 2013 Mar 8]. (Statistical Software Components). Available from: http://ideas.repec.org/c/boc/bocode/s43 2903.html

[35] Jann B. ESTOUT: Stata module to make regression tables [Internet]. Boston College Department of Economics; 2009 [cited 2013 Mar 8]. (Statistical Software Components). Available from: http://ideas.repec.org/c/boc/bocode/s439301.html

[36] Kohn LT, Corrigan JM, Donaldson MS. To Err is Human: Building a Safer Health System [Internet]. Institute of Medicine; 1999 Nov [cited 2013 Mar 11]. Available from: http://www.safety2011.com.br/artigos/ToErrIsH umam_BuildingaSaferHealthSystem_IOM2000.pdf

[37] Leape LL, Berwick DM. Five years after to err is human: What have we learned? JAMA. 2005 May 18; 293(19): 2384-90. PMid: 15900009. http://dx.doi.org/10.1001/jama.293.19.2384 